\title{
Design space definition for a stirred single-use bioreactor family from 50 to $2000 \mathrm{~L}$ scale
}

\author{
Thomas Dreher, Ute Husemann, Sebastian Ruhl, Gerhard Greller \\ From 23rd European Society for Animal Cell Technology (ESACT) Meeting: Better Cells for Better Health \\ Lille, France. 23-26 June 2013
}

\begin{abstract}
Background
Single-use bioreactors continue to gain large interest in the biopharmaceutical industry. They are excessively used for mammalian cell cultivations, e.g. production of monoclonal antibodies and vaccines [1]. This is motivated by several advantages of these bioreactors like reduced risk of cross contaminations or shortening lead times [2]. Singleuse bioreactors differ in terms of shape, agitation principle and gassing strategy [3]. Hence, a direct process transfer or scale-up between different systems can be a challenge. Reusable bioreactors are still regarded as gold standard due to their well-known and defined geometrical properties. Based on this knowledge a stirred single-use bioreactor family from 50 to $2000 \mathrm{~L}$ scale was developed with similar geometrical ratios like commonly used reusable systems. To follow a Quality by Design approach the key process parameters for a modern mammalian cell cultivation were specified. Therefore, the $\mathrm{k}_{\mathrm{L}} \mathrm{a}$-value, mixing time and the power input per volume were evaluated by using process engineering methods for all scales.
\end{abstract}

\section{Stirred single-use bioreactor family}

The used stirred single-use bioreactor family (BIOSTAT ${ }^{\circledR}$ STR, Sartorius Stedim Biotech, Germany) has design criteria similar to conventional reusable systems. The bioreactors have a cylindrical cultivation chamber, two impellers mounted on a rigid shaft and a submerged sparger. The H/D ratio of 2:1 and the impeller to bag ratio of 0.38 was kept constant for all scales [4]. There is the possibility to select between the impeller configuration $2 \times 3$ blade segment impeller (downward mixing) and 6-blade disk (bottom) +3 -blade segment (top) impeller. For the process engineering characterization $2 \times 3$-blade segment impellers were used. The aeration was performed by a combi sparger, which consists a ring sparger part (hole

\footnotetext{
* Correspondence: thomas.dreher@sartorius-stedim.com Sartorius Stedim Biotech GmbH, Göttingen, Germany, D-37079
}

diameter $0.8 \mathrm{~mm}$ ) and a micro sparger part (hole diameter $0.15 \mathrm{~mm})$.

\section{Process engineering characterisation \\ Design space approach}

The field of application of the stirred single-use bioreactor family is the cultivation of mammalian cells. To verify the single-use bioreactors a modern $\mathrm{CHO}$ process was considered with a peak cell density of $27-28 \times 10^{6}$ cells $/ \mathrm{mL}$. This process defines the key process parameters relevant for the design space definition [3,5], which are a moderate shear rates (tip speeds $<2.0 \mathrm{~m} / \mathrm{s}$ ), a sufficient oxygen transfer rate $\left(\mathrm{k}_{\mathrm{L}} \mathrm{a}>7 \mathrm{~h}^{-1}\right.$, supply pure oxygen assumed), a suitable homogeneity (mixing times $<60 \mathrm{~s}$ ) and a power input per volume $\left(\mathrm{P} / \mathrm{V}_{\mathrm{L}}\right)$ between 10 and $250 \mathrm{~W} / \mathrm{m}^{3}$ (from lab to production scale).

\section{Power input per volume}

Energy has to be transferred to a bioreactor to ensure cell suspension, homogenization and gas dispersion [6]. For the quantification the dimensionless Newton number $(\mathrm{Ne})$ was determined by torque measurements [3]. From the results the power input per volume was calculated for tip speeds between 0.6 and $1.8 \mathrm{~m} / \mathrm{s}$. Ne for the selected configuration was 1.3 . Figure 1 a shows the $P / V_{L}$ characteristics, which increased for all scales with the tip speed. With increasing size of the CultiBag STR the power input per volume decreases at a defined tip speed.

\section{Mixing time}

Appropriate mixing is important to avoid concentration or temperature gradients inside the cultivation chamber. The mixing time of the stirred single-use bioreactor was determined by the decolourization method [7]. The mixing times as a function of the tip speed are illustrated in Figure 1b. As the tip speed increases, expectedly the 


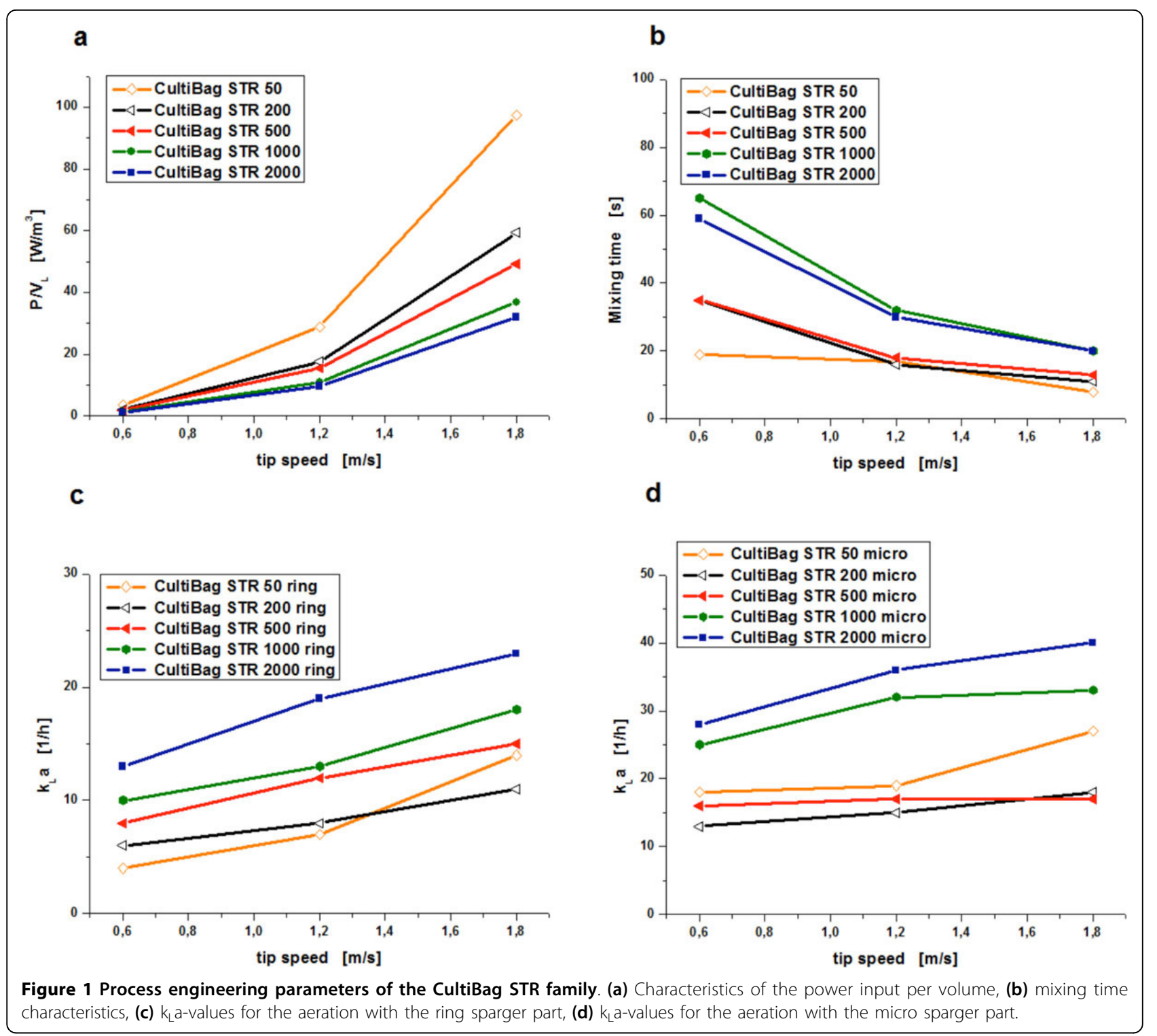

mixing times decrease. For all scales mixing times below $30 \mathrm{~s}$ are achieved.

\section{Oxygen transfer capabilities}

The oxygen transfer efficiency of a bioreactor can be described by the $\mathrm{k}_{\mathrm{L}} \mathrm{a}$-value, which was determined by the gassing-out method (1xPBS, room temperature) [8]. The aeration was carried out through the holes with $0.8 \mathrm{~mm}$ (ring sparger part) (Figure 1c) and in another trial through the holes with $0.15 \mathrm{~mm}$ diameter (micro sparger part) (Figure 1d). The volumetric mass transfer coefficients were determined as a function of the tip speed for a constant gas flow rate of $0.1 \mathrm{vvm}$. With increasing tip speed the $\mathrm{k}_{\mathrm{L}} \mathrm{a}$-value characteristics increased for all scales. For larger scales higher $\mathrm{k}_{\mathrm{L}} \mathrm{a}$-values were achieved presumably due to longer residence times of the gas bubbles. By using aeration through the holes with the smaller diameter the $\mathrm{k}_{\mathrm{L}} \mathrm{a}$-value can be significantly increased.

\section{Conclusions}

The main application of the presented single-use bioreactor family is the cultivation of mammalian and insect cells. These cells have special demands on the cultivation system for their optimal growth. To verify the suitability of the bioreactor family different process engineering parameters were determined. Based on the results the process engineering parameters are in the desired ranges of the defined design space regarding the power input per volume, mixing efficiency and the $\mathrm{k}_{\mathrm{L}} \mathrm{a}$-value. This indicates that the stirred single-use bioreactor family is suitable for cell culture applications. The design criteria of the CultiBag STR family directly relates to those from reusable 
systems. Therefore, existing challenges for a scale-up or process transfer are removed due to the improved design. Consequently, this technology represents an important step towards further maturity of single-use bioreactors and their acceptance.

Published: 4 December 2013

\section{References}

1. Brecht R: Disposable Bioreactors: Maturation into Pharmaceutical Glycoprotein Manufacturing. Adv Biochem Engin/Biotechnol 2009, 115:1-31.

2. Eibl D, Peuker T, Eibl R: Single-use equipment in biopharmaceutical manufacture: a brief introduction. In Single-use technology in biopharmaceutical manufacture. Wiley, Hoboken;Eibl R, Eibl D 2010:3-11.

3. Löffelholz C, Husemann U, Greller G, Meusel W, Kauling J, Ay P, Kraume M, Eibl R, Eibl D: Bioengineering Parameters for Single-Use Bioreactors: Overview and Evaluation of Suitable Methods. Chem Ing Tech 2013, 85:40-56.

4. Noack U, Verhoeye F, Kahlert W, Wilde D de, Greller G: Disposable stirred tank reactor BIOSTAT ${ }^{\oplus}$ CultiBag STR. In Single-use technology in biopharmaceutical manufacture. Wiley, Hoboken; Eibl R, Eibl D 2010:225-240.

5. Ruhl S, Dreher T, Husemann U, Jurkiewicz E, Greller G: The successful transfer of a modern $\mathrm{CHO}$ fed-batch process to different single-use bioreactors. Poster ESACT Lillé 2013.

6. Storhas W: Aufgaben eines Bioreaktors. Bioreaktoren und periphere Einrichtungen Vieweg \& Sohn Verlagsgesellschaft, Braunschweig/Wiesbaden; 1994, 15-86

7. Zlokarnik M: Bestimmung des Mischgrades und der Mischzeit Rührtechnik, Theorie und Praxis, Springer-Verlag Berlin Heidelberg New York 2002, 97-99.

8. Wise W S: The measurement of the aeration of culture media. J Gen Microbiol 1951, 5:167-177.

doi:10.1186/1753-6561-7-S6-P55

Cite this article as: Dreher et al.: Design space definition for a stirred single-use bioreactor family from 50 to $2000 \mathrm{~L}$ scale. BMC Proceedings 2013 7(Suppl 6):P55.

\section{Submit your next manuscript to BioMed Central and take full advantage of:}

- Convenient online submission

- Thorough peer review

- No space constraints or color figure charges

- Immediate publication on acceptance

- Inclusion in PubMed, CAS, Scopus and Google Scholar

- Research which is freely available for redistribution

Submit your manuscript at www.biomedcentral.com/submit
C Biomed Central 